\title{
Manda Eti Üretimi ve Kalite Özellikleri
}

\author{
Yusuf Konca $^{1}$, Asiye Y1lmaz Adkinson ${ }^{2 *}$ \\ Erciyes Universitesi, Ziraat Fakültesi, Zootekni Bölümü, 38039, Melikgazi-Kayseri, Türkiye, (ORCID: 0000-0002-6231-1512), yusufkonca@erciyes.edu.tr \\ ${ }^{2}$ Erciyes Universitesi, Ziraat Fakültesi, Zootekni Bölümü, 38039, Melikgazi-Kayseri, Türkiye, (ORCID:0000-0003-0311-5965), ayadkinson@erciyes.edu.tr
}

(İlk geliş tarihi: 03 Ekim 2021 ve Kabul tarihi 16 Aralık 2021)

(DOI: 10.31590/ejosat.1003259)

ATIF/REFERENCE: Konca, Y. \& Y1lmaz Adkinson, A. (2021). Manda Eti Üretimi ve Kalite Özellikleri. European Journal of Science and Technology, (31), 420-428.

\section{$\ddot{O} z$}

Bu derlemede manda etinin kalite özellikleri ve et kalitesine etki eden etmenler üzerinde yapılan çalışma sonuçları değerlendirilmiştir. Mandaların sığırlara göre canlı ağırlık kazanımları bir miktar düşük olmakla birlikte, düşük kaliteli mera ve yemlerden iyi bir şekilde yararlanmaları onları besi hayvanı olarak avantajlı kılmaktadır. Manda eti, Asya ülkeleri ve Türkiye'de genellikle yaşlı ve damızlık dışı kalmış mandalardan elde edilmekte ve bu nedenle karkas kalitesi de düşük olmaktadır. Manda eti sığır etine göre daha koyu kırmızı renkli ve kas lifleri arasındaki yağ oranı düşüktür ve etteki yağ oranın düşüklüğü ve etin koyu kırmızı renkli oluşu, etin diğer endüstriyel ürünlere işlenmesinde önemli avantajlar sağlamaktadır. Manda eti benzer yaşta kesilmiş sığır etleri ile kıyaslandığında besin madde içerikleri, organoleptik özellikler, etin sululuğu ve gevrekliği bakımından benzer özellikler taşıdığı belirlenmiştir. Bununla birlikte manda eti alımında daha düşük bir fiyat verilmekte ve bu durum üretici gelirini düşürmektedir. FAO'ya göre manda eti hak ettiği fiyatın altında satışa sunulmaktadır. Manda etleri besin madde içerikleri bakımından sığır etlerine benzer olduğu ancak kolesterol bakımından düşük olduğu ve insan sağlığını destekleyici olduğu sonucuna varılmıştır.

Anahtar kelimeler: manda, et üretimi, yă̆ asitleri, et kalitesi

\section{Buffalo Meat Production and Quality Characteristics}

\begin{abstract}
In this review, the results of studies on the quality characteristics of buffalo meat and the factors affecting meat quality were evaluated. Although the live weight gain of buffaloes is slightly lower than cattle, their high feed efficiency of poor quality pasture and feeds makes them advantageous as livestock. Buffalo meat is generally obtained from old, unproductive buffaloes in Asian countries and Turkey, and therefore the carcass quality may be low. Buffalo meat is darker red in color than beef, the fat content between muscle fibers is low, and the low fat content in meat and the dark red color of meat provide significant advantages in processing meat into other industrial products. It was determined that buffalo meat had similar properties in terms of nutrient content, organoleptic properties, juiciness and tenderness of the meat when compared to beef cuts of similar age. However, a lower price is given for the purchase of buffalo meat and this reduces the income of the producer. According to FAO, buffalo meat is offered for sale below the price it deserves. It was concluded that buffalo meats are similar to beef in terms of nutrient content, but lower in cholesterol and support human health.
\end{abstract}

Keywords: buffalo, meat production, fatty acids, meat quality

*ayadkinson@erciyes.edu.tr 


\section{Giriş}

Günümüz nüfus artış oranı aynı hızıyla devam ederse Dünya nüfusu 2050 yılında 9-10 milyar insan sayısına ulaşacağı ve gıda ihtiyacının da yaklaşık \%50 artacağı tahmin edilmektedir (FAOStat, 2019). Gerek dünya nüfusunun artış1 ve gerekse toplumların gelir düzeylerindeki iyileşmeler hayvansal ürün tüketiminin artmasına ve dolayısıyla et üretimine olan ihtiyacın artmasına neden olacaktır. Dünya genelinde kırmızı et üretiminin birinci kaynağı sığırlardır ve bunu domuz, koyun, keçi ve mandalardan elde edilen et üretimi izlemektedir (FAOStat, 2019), beyaz et üretiminde ise etlik piliçler en önemli kaynak durumundadır (Daghir ve ark., 2021). Et üretimi için kullanılan kanatlı hayvan yemlerinde mısır ve buğday gibi tahıllar bulunmakta ve bu kaynaklar insanlar için de önemli gıda kaynakları oldukları için bir rekabet oluşmaktadır. Sığır, koyun ve keçi gibi hayvanlar önemli et ve süt üretim kaynağıdır ve kanatlılara göre daha az kesif yemlere ihtiyaç duyarlar. Mandalar dünyada başta Asya ülkeleri olmak üzere belli bölgelere dağılmışlardır ve sayıları diğer çiftlik hayvanlarına göre daha azdır (FAOStat, 2019), ancak diğer hayvan gruplarına göre daha olumsuz şartlarda beslenmeye uygundurlar. Bu bakımdan kanatlı ve ruminant hayvanlar içerisinde insan gıdası ile en az rekabet edebilecek hayvanlar mandalardır. Ayrıca mandaların yüksek hastalık direnci ve geniş bir barınma, besleme ve sürü yönetim esnekliği onları avantajlı kılmaktadır (Wanapat and Kang, 2013).

Mandaların bazı beslenme özellikleri onları diğer hayvan gruplarına göre avantajlı kılmaktadır. Örneğin sığırlara göre mandalar daha düşük kuru madde tüketimine sahiptirler (Terramoccia ve ark., 2000). Ayrıca, mandaların selüloz ve proteinden yararlanma düzeyleri sığır ve koyunlara göre daha iyidir ve düşük kaliteli kaba yemleri daha iyi sindirme kabiliyetleri nedeniyle olumsuz şartlara daha iyi adapte olabilmektedirler. Mandalar, kaba yem kaynağı olarak saman ve mahsul artıkları ile hem yaşamlarını sürdürebilirler ve hem de proteince zengin, yağsız, kolesterol seviyesi düşük et üretebilirler (Sarwar ve ark., 2009). Mandalar, sığır ve koyun gibi ruminant hayvanlara göre daha uzun süreyle verimliliklerini devam ettirebilirler. Dolayısıyla beslenme kaynakları bakımından insanlarla daha az rekabetçi olan ve uzun bir ömür boyunca kötü bakım ve besleme şartlarında yararlanma imkânı olan bu hayvanlardan sürdürülebilir bir et üretimi için yararlanmak mümkündür. Ancak, bu güne kadar mandalara yeterli önem verilmemiş ve diğer hayvanlar gibi ciddi sslah ve besleme çalışmaları yapılmamıştır. Islah çalışması olarak, bilinen tek ilerleme, et verimini artırmaya yönelik olarak Trinide ve Tabaga adalarında Bufalypso 1rkı geliştirilmesidir (Irurueta ve ark., 2008). Buna rağmen mandalar sıcak ve sert tropikal iklim ve kötü bir besleme koşullarında sığırlara göre daha iyi bir büyüme göstermektedirler. Eğer mandalara iyi bir bakım ve besleme uygulanırsa et verimi ve kalitesi yüksek ve aynı zamanda yetiştirme masrafları daha düşük olabilmektedir (Astuti ve ark., 2019).

Pek çok ülkede et elde edilen mandalar kırsal alanlarda, sürülerden ayıklanan ve verim dönemi sona ermiş yaşlı hayvanlardan oluşmaktadır (Nanda ve Nakao, 2003). Yaşlı ruminant hayvanlardan elde edilen etlerin sertliği ve lezzetsizliği nedeniyle etin duyusal özelliklerinde azalmayla karakterize edilen bir durum ortaya çıkmakta (Ziauddin ve ark., 1994) ve aynı zamanda et üretim kaynağı sürekliliği ve güvenirliği bakımından iyi bir durum oluşturmamaktadır (Naveena ve Kiran, 2014). Ayrıca, mevcut piyasa koşullarında manda eti et toptancıları tarafindan (kasaplar), sığır ve koyun etlerine göre daha ucuz bir fiyatla alınmaktadır (genellikle \% 10-20 daha düşük, kişisel görüşmeler) ve dolayısıyla manda üreticisi için düşük gelir elde edilmesine neden olmaktadır. Bununla birlikte, manda etleri toptan alım fiyatına uygun olarak perakende daha ucuza satılırsa, düşük gelire sahip toplumlarda ucuz protein kaynağı olarak kullanilabilirler (Ranjhan, 2013).

Manda malaklarının doğum ağırlığı 20-30 kg civarındadır (Uğurlu ve ark. 2016; Kul ve ark. 2018), ileri yaşlarda erkekleri 450-550 kg ve dişileri 420-450 kg ağırlığa ulaşabilmekte, ilk kızgınlığını 24-36 aylık yaşta ve 250-275 kg canlı ağırlık (CA)'ta iken göstermekte ve ilk buzağılama yaşı 4-5 yaşları arasında olmaktadır (Yılmaz Adkinson and Konca, 2021). Bu özellikleri bakımından sığırlara göre önemli bir dezavantaja sahiptir ve ayrıca sığırlara göre buzağılama aralıkları daha uzundur. Et kalitesi ve bileşimini ırk, genetik yapı, yetiştirme sistemi ve kesim çağı etkileyebilmektedir (Ulutaş ve ark., 2021; Aksoy ve ark., 2021). Yapılan bir çalışmada, farklı kesim ağırlıklarında (200, 250,300 ve $350 \mathrm{~kg}$ ) bulunan erkek manda malaklarında kesim ağırlığı arttıkça sıcak ve soğuk karkas oranı ve karkas soğutma firesinin arttığı ve karkas parçaları ile yenilebilir iç organ ağırlıklarının farklılık gösterdiğini bildirilmiştir. Ayrıca, araştırıcılar kesim yaşının $350 \mathrm{~kg}$ ulaşmadan mandaların kesime sevk edilmemesi gerektiğini bildirmişlerdir (Ulutaş ve ark., 2021).

Son yıllarda yaşanan küresel 1sınma, salgın hastalıklar, bölgesel afetler ve ekonomik krizler dünyada besin kaynakları üretimini ve beslenme alışkanlıklarını önemli düzeyde değişime zorlamaktadır. Manda eti kırmızı etler içerisinde düşük yağ ve kolesterol içeriği nedeniyle sağlıklı etler içerisinde yer almaktadır (Kandeepan ve ark., 2013), dolayısıyla sağlık bilincine sahip olan tüketicilerin tercih edebileceği yağsız et sağlayabilmektedir. Son yıllardaki gıda krizleri ve ekonomik darboğazalar nedeniyle genel olarak Dünyada kırmızı et tüketimi 1990'lardan sonra giderek azaltmaktadır (Bonnet ve ark., 2020). Bu azalışı önlemek için daha ucuz et kaynakları temin edebilen hayvanlara yönelmek faydalı olabilir.

$\mathrm{Bu}$ derlemede, önemli bir et üretim potansiyeli bulunan mandalarda et verimi ve kalite özellikleri incelenmiş ve gelecek için insan beslenmesinde kullanım potansiyeli değerlendirilmiştir.

\section{Dünya Kırmızı Et Üretimi ve Manda Etinin Payı}

Dünyada son 40 yıllık dönemde kırmızı et üretimi ve hayvan ırklarına göre elde edilen et miktarları ve \% değişim oranları Tablo 1'de verilmiştir. Dünyada kırmızı et üretimi miktarları 1980 yılı temel alınarak hesaplandığında 2019 yılına kadar sürekli bir artış içerisinde olduğu ve bu artışın yaklaşık 40 yıl içerisinde $\% 62,86$ arttığı belirlenmiştir. Diğer yandan sığır, koyun, keçi ve manda eti üretimi miktarlarındaki değişim oranı 1980 ila 2019 yılları arasında sirasıyla; \%28,82, 41,08, 134,54 ve 89,26 olarak gerçekleşmiştir. En yüksek değişim keçilerden elde edilen et 
miktarında olmuş, manda etinin artış oranı \%89,26'lık oran ile sığır ve koyun eti üretiminden daha yüksek olmuştur (Tablo 1). Toplam kırmızı et üretiminin yıllar itibariyle değişimi incelendiğince 1980, 1990, 2000, 2010, 2015 ile 2019 y1lları arasındaki değişim sırasıyla; \%19,23, 29,22, 47,16, 52,19 ve 62,86 olarak gerçekleşmiştir. Dünyada toplam ve bazı kıtalardaki kesilen manda sayıları Tablo 2'de verilmiştir. Tablo 2'nin incelenmesinden görülebileceği gibi kesilen manda sayıları Dünya toplamı bakımından sürekli artış göstermiş ve 1980 yılına göre kesilen manda sayısı 2019 yılında \%131,32 olmuştur.

Tablo 1. Hayvan türlerine göre dünyada kırmızı et üretimi miktarları (ton) ve \% değişimleri

\begin{tabular}{|c|c|c|c|c|c|c|}
\hline \multicolumn{7}{|c|}{ Yillar } \\
\hline & Siğır & Koyun & Keçi & Manda & Toplam & $\begin{array}{c}\text { Toplam \% } \\
\text { değişim }\end{array}$ \\
\hline 1980 & 45565944 & 5646954 & 1693540 & 1605905 & 54512343 & - \\
\hline 2000 & 55832379 & 7717166 & 3879275 & 3014411 & 70443231 & 29,22 \\
\hline 2010 & 62646774 & 8483431 & 5188378 & 3901558 & 80220141 & 47,16 \\
\hline 2015 & 63847528 & 9437953 & 5647780 & 4028373 & 82961634 & 52,19 \\
\hline
\end{tabular}

FAOStat, 2021

Aynı yıllarda Türkiye'de kesilen manda sayılarında ise çok ciddi bir azalma $(-\% 99,64)$ meydana geldiği görülmektedir. Ancak Türkiye'de ki manda sayısı (168000) göz önüne alındığında ve doğan malakların yaklaşık yarısının erkek olduğu varsayılırsa, bu miktarın besiye alınması ve kesime sevki durumunda elde edilecek rakamın daha yüksek olabileceği düşünülebilir.

Tablo 2. Dünyada ve bazı kıtalarda kesilen manda sayısı (baş) ve \% değişim oranları

\begin{tabular}{|c|c|c|c|c|c|c|}
\hline \multicolumn{7}{|c|}{ Yillar } \\
\hline & 1980 & 1990 & 2000 & 2010 & 2015 & 2019 \\
\hline Dünya & 11971663 & 16265642 & 20484008 & 25783012 & 26359309 & 27692388 \\
\hline Afrika & 934078 & 1215000 & 1640000 & 1262000 & 1179000 & 1088548 \\
\hline Asya & 11007703 & 15040014 & 18834206 & 24487796 & 25073166 & 26469363 \\
\hline Avrupa & 29882 & 10628 & 9802 & 33216 & 87544 & 104776 \\
\hline Türkiye & 94950 & 82880 & 23518 & 15720 & 1391 & 338 \\
\hline \multicolumn{7}{|c|}{ Değişim, \% (1980 yılına göre) } \\
\hline Dünya & - & 35,87 & 71,10 & 115,37 & 120,18 & 131,32 \\
\hline Türkiye & - & $-12,71$ & $-75,23$ & $-83,44$ & $-98,54$ & $-99,64$ \\
\hline
\end{tabular}

FAOStat, 2021

Dünyada ve bazı kıtalarda yıllara göre manda eti üretimi miktarları Tablo 3'te verilmiştir. Dünya manda eti üretimi 1980 ila 2019 yılları arasında \%167 oranında artış göstermiş, benzer artış Afrika, Asya, Avrupa kıtalarında sırasıyla \%204,66, 162,97 ve 414,68 olmuştur. Türkiye'de ise manda eti üretimi 1980 ila 1990 yılları arasında \%7,36'lık bir artış olmuş, ancak bu değişim 1980 yılına göre 2019 yılında \%-99,32 azalma ile sonuçlanmıştır. Türkiye'de manda eti üretimindeki 2010 yılından sonraki azalışın bir nedeni 2011 yılında uygulamaya alınan manda ıslahı ile hayvan sayısının artırılmaya çalışılması nedeniyle özellikle dişi hayvanların kesimindeki azalma sonucu olabileceği düşünülmektedir. Aynı zamanda sığır yerine kesilerek kaydının kesimhanelerde sığır olarak işlenmesi ise diğer bir sebep olabilir. 
Tablo 3. Dünyada ve bazı kıtalarda manda eti üretimi (ton)

\begin{tabular}{|c|c|c|c|c|c|c|}
\hline & & & Yillar & & & \\
\hline Ülkeler & 1980 & 1990 & 2000 & 2010 & 2015 & 2019 \\
\hline Dünya & 1605905 & 2266850 & 3014411 & 3901558 & 4028373 & 4290212 \\
\hline Afrika & 120000 & 161000 & 288000 & 398353 & 407119 & 365588 \\
\hline Asya & 1481771 & 2103644 & 2724577 & 3496432 & 3598781 & 3896627 \\
\hline Avrupa & 4134 & 2206 & 1834 & 6773 & 17947 & 21277 \\
\hline Türkiye & 10660 & 11445 & 4047 & 3387 & 326 & 73 \\
\hline \multicolumn{7}{|c|}{ Değişim, \% (1980 yılına göre) } \\
\hline Dünya & - & 41,16 & 87,71 & 142,95 & 150,85 & 167,15 \\
\hline Afrika & - & 34,17 & 140,00 & 231,96 & 239,27 & 204,66 \\
\hline Asya & - & 41,97 & 83,87 & 135,96 & 142,87 & 162,97 \\
\hline Avrupa & - & $-46,64$ & $-55,64$ & 63,84 & 334,13 & 414,68 \\
\hline Türkiye & - & 7,36 & $-62,04$ & $-68,23$ & $-96,94$ & $-99,32$ \\
\hline
\end{tabular}

FAOStat, 2021

Dünyada ve bazı ülkelerde kesilen manda sayısı (baș), birim karkas verimi ve kesilen hayvanların toplam manda sayılarına oranı Tablo 4'te verilmiş̧tir. Tablo 4 'te manda sayılarına göre ülkeler sıralanmış, toplam manda sayılarına göre kesilen manda sayıları oranlanmıștır. Manda sayısı, manda eti üretimi ve kesilen manda baş sayısı bakımından Hindistan en yüksek rakamlara sahiptir. Bununla birlikte gerek kesilen miktarın toplam manda sayısına oranı ve gerekse elde edilen karkas verimi bakımından birçok ülkeye göre Hindistan daha düşük düzeydedir. Toplam manda sayıs1 / kesilen manda sayısı oranı en yüksek ülke \%31,31 ile Misır ve en düşük ülke olarak ise $\% 0,19$ ile Türkiye ve takiben Bangladeş $(\% 4,54)$ yer almaktadır. Karkas verimleri bakımından değerlendirildiğinde hayvan başına en düşük karkas verimi $80 \mathrm{~kg}$ ile Bangladeş'tir ve en yüksek karkas verimi elde edilen ülke $343,44 \mathrm{~kg}$ ile İran olmuştur.

Tablo 4. Dünyada ve bazı ülkelerde kesilen manda sayısı (baş), birim karkas verimi ve kesilen hayvanların toplam manda sayıları*

\begin{tabular}{|c|c|c|c|c|c|}
\hline Ülke & Manda sayısı, baş & $\begin{array}{l}\text { Manda et üretimi, } \\
\text { ton }\end{array}$ & $\begin{array}{l}\text { Kesilen manda sayıs1, } \\
\text { baş }\end{array}$ & $\begin{array}{l}\text { Birim karkas } \\
\text { verimi, kg }\end{array}$ & $\begin{array}{l}\text { Kesilen/ toplam } \\
\text { oran1, \% }\end{array}$ \\
\hline Hindistan & 109851678 & 1616853 & 11682255 & 138,4 & 10,63 \\
\hline Pakistan & 40002000 & 1085000 & 7647000 & 141,89 & 19,12 \\
\hline Çin & 27336130 & 658447 & 4460266 & 147,63 & 16,32 \\
\hline Myanmar & 4082914 & 54203 & 381881 & 141,94 & 9,35 \\
\hline Misir & 3476396 & 365588 & 1088548 & 335,85 & 31,31 \\
\hline Vietnam & 2387887 & 94479 & 426306 & 221,62 & 17,85 \\
\hline Bangladeş & 1490000 & 5412 & 67654 & 80 & 4,54 \\
\hline Brezilya & 1434141 & & - & - & - \\
\hline Endonezya & 1141298 & 23972 & 133109 & 180,09 & 11,66 \\
\hline İtalya & 402290 & 21277 & 104776 & 203,07 & 26,04 \\
\hline Türkiye & 178397 & 73 & 338 & 215,98 & 0,19 \\
\hline İran & 72434 & 4725 & 13758 & 343,44 & 18,99 \\
\hline Dünya & 204342419 & 4290212 & 27692388 & 154,92 & 13,55 \\
\hline
\end{tabular}

*FAOStat 2019

\section{Mandaların Karkas ve Et Özellikleri}

Mandalardan elde edilen karkas verimleri ve et kalite özellikleri bakımından farklı yönlerden incelenmesi gerekir. Büyükbaş hayvanların kesim randımanı karlılığı etkileyen önemli faktörlerdendir. Lambertz ve ark. (2014) bataklık mandalarında kesim randımanının \%48-49, nehir mandalarında ise bu oranın $\% 50-55$ arasında olduğu ve Çin'de yaşayan binlangjang mandalarında kesim randımanının \%52-55 olduğu ve yaş ilerledikçe karkas randımanının düştüğü bildirilmiştir ( $\mathrm{Li}$ ve ark., 2018). Irurueta ve ark. (2008) 18 aylikken kesilen manda malaklarının kesim randımanlarının $\% 50$ olduğunu bildirmişlerdir. $\mathrm{Bu}$ verilere göre nehir mandalarının kesim randımanları sığırlardan elde edilen kesim randımanlarına (\%5055) (Duru ve Sak, 2017) yakın olduğunu göstermektedir.
Irurueta ve ark. (2008) USDA'nın sığır karkas özellikleri ölçeğine göre, manda karkaslarının sığır karkaslarına göre daha az göz kası alanı ve etlerinde daha az mermerleşmeye sahip olduğunu ve $592 \mathrm{~kg}$ canlı ağırlığındaki bir bataklık mandasının karkas veriminin $277 \mathrm{~kg}$ ve et veriminin $215 \mathrm{~kg}$ olduğu bildirmişlerdir. Giuffrida-Mendoza ve ark., (2015) manda ve brahman sığırlarında taze kastaki \% yağ ve kolesterol oranının türler arasında ve kesim yaşlarında farklılık göstermediğini bildirmişlerdir. Ayrıca yeterli protein ve enerji içeren iyi kaliteli yemlerle entansif şartlarda yetiştirilen manda malaklarının günde 0,9 ile 1,0 kg civarında CA alabildiklerini göstermiştir (Ranjhan, 2013). Bir çalışmada manda malaklarının 300, 350, 400 ila 450 $\mathrm{kg}$ canlı ağırlıklarda kesildiklerinde kemiksiz et oranının $\% 36,6$ ila 39,0 arasında değiştiğini ve kemik oranının \%9,3 ila 11,0 arasında değiştiğini bildirmişlerdir (Rashad ve ark., 2019). Çalışmalar besleme yöntemleri ve kesim yaşının (20 ila 34 aylık) 
manda etinin yumuşaklık ve lezzetliliğine önemli derecede etki etmediğini belirtmişlerdir ve yakın yaşlarda kesilen sığırlarla benzer olduğunu göstermiştir (Charles, 1982).

Hindistan gibi bazı ülkelerde mandalardan elde edilen etlerin \%85'i sürüden ayıklanan mandalardan elde edildiği (Kiran ve ark., 2016), ileri yaşlı hayvanların kesilmesi nedeniyle de çoğu tüketicinin manda etlerini koyu siyah ve oldukça sert olarak niteledikleri bildirilmiştir. Manda etinin yağsız olması, farklı ürünlerde kullanımını artırılabilmekte ve koyu kırmızı görünüşteki et rengi nedeniyle iyi bir bağlayıcı ve endüstride katma değerli et ürünleri geliştirilmesine uygun olmaktadır (Naveena ve Kiran, 2014). Bununla birlikte bazı araştırmalarda manda etinin yumuşaklığının sığır etine benzediği ve düşük kolesterol içeriği nedeniyle avantajlara sahip olduğu bildirilmiştir (Paleari ve ark., 1997). Manda eti kalitesi genellikle sığır eti ile karşılaştırılarak çalışılmış ve bu iki et arasında çeşitli et kalite özellikleri ve duyusal nitelikler için birçok benzerlikler bildirilmiştir (Neath ve ark. 2007; Tateo ve ark. 2007; Joksimovic and Ognjanovic 1977). Manda etinin, sığır eti ile karşılaştırılabilir fiziko-kimyasal, biyokimyasal ve teknolojik özelliklere sahip olduğu belirtilmektedir (Kandeepan ve ark., 2009).

Taze manda etinin miyoglobin içeriği, kas tipine ve hayvan yaşına bağlı olarak 2,7 ila 9,4 mg/g arasında değişmekte ve yaş arttıkça et daha koyu hale gelmektedir (Valin ve ark., 1984). Irurueta ve ark. (2008) farklı yaş gruplarındaki manda eti için 12,0 ile 20,0 arasında değişen kırmızılık skorları (a*) bildirmiştir. Manda eti koyu kırmızı renkli ve yağı ise beyaz renkli ve serttir (Joksimovic ve Ognjanovic, 1977). Abdolghafour and Saghir (2014) manda etinin koyu kırmızı renkte olmasının daha az kas içi yağ veya daha fazla pigmentasyondan kaynaklandığını bildirmişlerdir.

Kırmızı etlerin tercihinde içerdiği besin maddeleri önemli olmakla birlikte, etin parlaklığı tüketicinin satın alma tercihini etkileyen önemli unsurlardandır (Banović ve ark., 2009). Ayrıca, etin satın alındıktan sonra sertliği, sululuğu, kokusu ve lezzeti gibi duyusal özellikler de et alım tercihlerini etkilemektedir (O'Quinn ve ark., 2018). Manda eti genel olarak market ve kasaplarda yaygın olarak satışı bulunmayan etlerdendir. Manda eti gibi az bilinen etlerin kıyaslaması, sığır ve koyun etlerinin görünüş ve duyusal özelliklerine göre yapılmaktadır. Ancak, Türkiye'de marketlerde ve kasaplarda manda etinin satışta bulunmaması nedeniyle etler arasında bir kiyaslama yapılamamaktadır. Bununla birlikte, manda eti sığır eti ile organoleptik, kompozisyon, besleyicilik, fonksiyonellik ve fiziko-kimyasal kalite özellikleri bakımından aşağı yukarı benzer olduğu, hatta manda etinin yağsız, kalorisi ve kolesterol içeriğinin daha düşük olması nedeniyle avantajları bulunduğu bildirilmiştir (Naveena ve Kiran, 2014).

Sığırların da ileri yaşlarda kesilmeleri durumunda kas liflerini saran bă̆ dokuların sertleşmesi nedeniyle etin gevrekliğinde önemli bir azalma olduğu ve bu durumda daha çok genç hayvanların besiye alınarak bir ile iki yaş civarlarında kesildikleri bilinmektedir. Mandalarda da kesim yaşı öne alındığında etlerinin daha açık renkli ve et kalite özelliklerinin daha yüksek olabileceği gösterilmiştir (Kandeepan ve ark., 2013). Yük hayvanı olarak kullanılan mandalar yaşlanıp çalışma yeteneklerini kaybettiklerinde ve 12 ila 13 yaşlarında kesime sevk edilmektedirler (Tuyen ve Ly, 2001) ve tüketicilerin alışkanlıkları ve geleneksel düşünceleri nedeniyle sığır etinden daha düşük bir fiyata satılmaktadırlar (Ly, 2001).
Günümüzde mandaların birincil amaç olarak süt üretimi için yetiştirilmeleri ve sütten elde edilen gelirin ön planda olması nedeniyle erkek buză̆ıların içtikleri sütten tasarruf etmek amaciyla bazen ölüme terkedilmekte veya beslenme ve bakımlarına özen gösterilmemektedir (Pathak ve ark., 1987). Erkek manda malaklarının sığırlarda olduğu gibi besiye alınmaları ve et kaynağı olarak değerlendirilmeleri durumunda hem et endüstrisine katkı sağlayabilirler ve hem de iyi kaliteli et üretimine katkıları bulunabilir (Borghese, 2013). Bunun aksine bazen de manda buzağıları, beyaz buzağı eti elde etmek amacıyla süt emme periyodunda $60-80 \mathrm{~kg}$ ağırlıkta ve erken yaşta kesilmektedirler ve bu durum manda eti üretimini negatif yönde etkilemektedir (USDA, 2018).

Robertson ve ark. (1986) birlikte çayır merada otlatılan ve aynı yaş (27 ay) ve kesim ağırlığında (ortalama $317 \mathrm{~kg}$ ) bulunun brahman ırkı sığırlar ve mandaların vücudun dört farklı bölgesinde alınan et özelliklerini karşılaştırdıkları bir çalışmada, manda etlerinin sığırlara göre daha koyu kırmızı renkli olduğunu ve soğutulmuş karkasta koyu rengin daha belirgin olduğunu bildirmişlerdir. Araştırıcılar, etteki bağ dokunun mandalarda daha fazla ve sığırlara göre etin daha sert olduğunu, Psoas major (PM) kası bakımından aralarında fark olmadığını ancak sığır etinin tercihinin daha iyi olduğu tespit edilmiştir.

Manda etinin sığır etine benzer su tutma kapasitesi, gevrekliği, yumuşaklığı ve mermerleşme (kas içi yağ dağılımı) bakımından benzer olması nedeniyle (Lapitan ve ark., 2007) sığır eti yerine satılabilir. Manda eti kırmızı renk, düşük yağ ve kolesterol, düşük bağ dokusu, yüksek protein, yüksek su tutma kapasitesi ve emülsifiye etme kapasitesi özellikleri nedeniyle üstün niteliklidir (Kandeepan ve ark., 2013).

Etin $\mathrm{pH}$ değeri etin rengini belirlediği için tüketicilerin satın alınma tercihini etkilemekte ve tüketiciler genellikle normal kırmızı renkli etleri tercih ederken koyu kırmızı etleri tercihi düşük olmaktadır (Acebrón ve Dopico, 2000). Manda etinin kimyasal bileşiminin ve kalite özelliklerinin manda türü ve cinsi, yaşı, beslenme yoğunluğu, yönetim sistemi ve çevre koşulları (Abdolghafour ve Ahmad Saghir, 2014), kesim döneminde stresli olmaları ve etin muhafazasından da kaynaklı olabilmektedir (Ziauddin ve ark., 1994). Valin ve ark. (1984) manda etinin sığır etinin $\mathrm{pH}$ değeri ve kollojen miktarının sığırlardan düşük olduğunu, fakat kaslar arasındaki bağ kollojeni bakımından türler arasında farklılık bulunmadığını bildirmişlerdir. Ziauddin ve ark. (1994) genç yaşta kesilen manda etlerindeki kollojen varlığının yaşlı mandalara göre daha düşük olduğunu ve yaşlı hayvanların kaslarında pişirme kaybı ve termal büzülme oranının genç hayvanlara göre daha yüksek olduğunu bildirmişlerdir. Abdolghafour and Saghir, (2014) manda etinin koyu renkli, iyi bağlama özelliklerine sahip ve ürün imalatında tercih edilebilir ve manda eti sosis gibi yemeye hazır ürün üretiminde kullanılabilir.

İtalya gibi bazı ülkelerde manda etine olan ilgi son yıllarda artmıştır. Ancak, önceki yıllarda kesilen hayvanların üreme ve verim problemleri olan hayvanların kesilmeleri ve bunların düşük et kaliteleri nedeniyle bu etlerin tüketiminden dolayı memnuniyetsizlik ortaya çıkmıştır (Borghese, 2010). Bununla birlikte yeterli besleme yöntemleriyle istenilen özellikleri sağlayan kaliteli et üretimi gerçekleştirilebileceği önerilmiştir (Infascelli ve ark., 2004).

Avrupa'da ilk manda yetiştiren ülke İtalya'dır. İtalya Ulusal Zootekni verilerine göre toplam 2208 çiftlikte 403093 baş hayvan manda yetiştirilmektedir. İtalya'daki manda urkı İtalyan Akdeniz ırkına aittir. Mandalar süt üretimi amacıyla yetiştirilmektedirler 
ve başta mozzarella peyniri olmak ürere diğer İtalyan peynirlerine (provola, scamorza, caciotta, caciocavallo vb.) işlenmektedirler. Ancak bu ülkedeki manda eti üretimi sınırlıdır, az sayıda üretici erkek buzağı yetiştiriciliği yapmaktadır (Tamburrano ve ark., 2019). İtalyan mandası ve simmental sı̆̆ırlarının karkas özelliklerinin incelendiği bir çalışmada dörder adet erkek manda ve simmental sığırı kullanılmıştır (Spanghero ve ark., 2004). Bu çalışmada mandaların sı̆̆ırlara göre daha yavaş büyüdükleri (930 g’a karşın 1040 g/gün canlı ağırlık artışı) belirlenmiştir. Ayrıca, mandaların vücut ve karkas uzunlukları sığırlardan daha kısa olduğu ancak karkas ağırlıkları bakımından benzer oldukları belirlenmiştir. Manda etlerinin renklerinin sığırlardan daha koyu kırmızı renkli ve yumuşak olduğu (manda ve sığır için sırasıyla, $a^{*}=$ kırmızılık: 23,7'ye karş1 18,8; kopma kuvveti: 46,3'e karş1 68,8 N) görülmüştür.

\section{Manda Etinin Besleyici Özellikleri}

Kırmızı etlerde önemli özelliklerinden birisi de başta protein olmak üzere besleyici madde içeriğidir. Etlerin besin madde içeriği, hayvanın genetiği, yaşı, yem ve kesim yaşına göre birçok faktöre bağlı olarak değişebilmektedir (Ulutaş ve ark., 2021; Marchello ve Driskell, 2001). Manda etlerinin sığır etlerine göre protein içeriğinin daha yüksek olduğunu bildiren çalışmalar olmakla birlikte, bazı çalışmalar (Ziauddin ve ark., 1994) manda etinin kimyasal bileşimi, sarkoplazmik ve miyofibriler protein içeriklerinin sığır etine benzediğini bildirmişlerdir. İtalya'da yapılan bir çalışmada, erkek mandaların Longissimus dorsi (LD) kasından alınan et örneklerinde protein oranının sığırlardan daha yüksek olduğu (\%21,13 ham protein), ayrıca her $100 \mathrm{~g}$ et için toplam serbest amino asit içeriğinin 155,79 ila $181,78 \mathrm{mg}$ arasında değiştiği bildirilmiştir (Landi ve ark., 2016). Ziauddin ve ark., (1994) manda eti lizin bakımından sığıra göre daha yüksek olduğunu bildirmişlerdir. Taze manda eti nem oranı \%74,04 ila $77,75 \%$ arasında değişmektedir (Naveena ve Kiran, 2014; Ziauddin ve ark., 1994; Anjaneyulu ve ark., 1985). Aksoy ve ark. (2001) farklı CA'ta (200 ila $350 \mathrm{~kg}$ arasında) kesilen erkek Anadolu mandalarında LD kasında ölçülen \% kuru madde (KM 25,71-26,02 arasında), kül (0,88-0,96 arasında), 24. saatteki $\mathrm{pH}$ (5,31-5,35 arasında), et rengi ve su tutma kapasitesinin önemli derecede farklılık göstermezken; etin ham protein değerinin azalırken $(22,10-23,13)$ yağ oranının arttığını $(1,79-3,01$ arasında) tespit etmişlerdir.

Yağdaki karotenler et yağının sarı renkli olmasına neden olur ve manda yağında karoten bulunmamaktadır. Manda eti daha yüksek protein, az yă ve düşük kolesterol içermektedir (Joksimovic ve Ognjanovic, 1977; Kandeepan ve Biswas, 2007). Ziauddin ve ark. (1994) kesim sonrası manda etlerini depolama sıcaklığı arttıkça ette $\mathrm{pH}$ değerinin düşüşünün daha hızlı olduğunu ve stresli hayvanlardan elde edilen etlerde $\mathrm{pH}$ değerinin daha yüksek olduğunu belirlemişlerdir. Valin ve ark. (1984), manda etlerinin sığır etlerine göre daha düşük pH'ya sahip olduğu, daha az kollojen içerdikleri ve ancak manda ve sığır etlerinin kas içi kollojen yapılarının önemli ölçüde farklılık göstermediğini belirlemişlerdir.

Kırmızı etlerin bileşimi; etin görünümü, sertliği, sulu olması ve duyusal özellikleri üzerine etki edebilmektedir (Suleman ve ark., 2020). Etlerdeki mermerleşme diye tabir edilen yağların kas dokusu içindeki dağılımı, etin görünümünü ve sululuğunu etkilemektedir. Etlerdeki doymuş yağ asitlerinin oranının yüksek oluşu damar sertliğine neden olabilir (Nordoy ve Goodnight, 1990) düşüncesiyle istenmemektedir. Yüksek miktarda doymamış yağ asidi içeriğine sahip yağlı etler gevşekliği nedeniyle de tercih edilmeyebilir. Diğer yandan etlerin omeaga-3, EPA, DHA ve konjuge linoleik asit (CLA) yağ asitlerince yüksek olması durumunda sağlık için önemli faydalar sağlayabildiğinden tüketici tercih edilme oranı artabilir (Giordano ve ark., 2010). Dimov ve ark. (2012) etteki lipidlerin yağ asidi içeriğini incelemek için bir yıl süreyle aynı yemlerle beslenen manda malağı ve sığır buzağılarının LD kasının incelenmesinde sığırlara kıyasla manda etinde daha yüksek oranda kuru madde, ham yağ ve ham protein tespit etmişlerdir.

Erkek mandalarda farklı kesim ağırlığının (200, 250, 300 ve $350 \mathrm{~kg}$ ) yağ asitleri üzerine etkileri ile ilgili yapılan bir çalışmada (Aksoy ve ark., 2021) erkek mandalarda kesim ağırlığı arttıkça MUFA oranın arttığı, PUFA/SFA oranın azaldığı, C18:1 yağ asidi

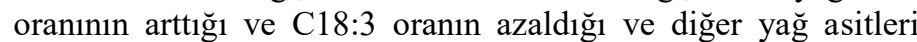
arasındaki farklıkların istatistiki olarak önemli olmadığ saptanmıştır.

Yapılan çalışmalarda manda karkaslarının farklı bölgelerinden alınan et örneklerinin besin madde ve yağ asidi içeriklerinin farklı olduğu belirlenmiştir (Sharma ve ark., 1986; Calabrò ve ark., 2014). Vücudun farklı bölgelerdeki kaslarda tespit edilen yă̆ asidi içeriği bakımından karşılaştırıldığında kas içi yağların \%44-55'inin doymuş yağlardan stearik ve palmitik asit oluşturduğu görülmüştür. Tekli doymamış yağ asitlerin (MUFA) \%31-40 arasında olduğu ve bu asitlerin \%90'ının oleik asitten meydana geldiği tespit edilmiştir. Çoklu doymamış yă asitleri (PUFA) bakımından PM, LD, Longissumus semitendinosus (ST) ve Biceps femoris (BF) kasları içeriklerinin sirasıyla, \%11, 12, 13 ve 16 olduğunu ve dominant PUFA yă asitlerinin sırasıyla linoleik (\%66) ve araşidonik (\%25) olduğu belirlenmiştir (Sharma ve ark., 1986). Ayrıca yapılan bir çalışmada (Calabrò ve ark., 2014) Akdeniz mandaların beslenmesinde kullanılan farklı protein kaynaklarının (bakla ve soya) etteki besin madde kompozisyonunu etkilediğini, bakla ile beslenen mandaların etlerinde yağ, protein, kolesterol ve doymuş yağ asidi oranının önemli derecede düşük bulunduğunu bildirmişlerdir. Aynı zamanda bu hayvanlarda analiz edilen kaslar arasında LD, ST ve PM kasları arasında önemli farklılıklar olduğu ve ST kaslarının düşük doymuş yağ asidi (SFA) ve yüksek PUFA, MUFA, omega-3, omega-6 ve CLA olduğunu bulmuşlardır. Sığır ve manda ST ve LD kas dokusundaki yăg asitlerinin bileşimi karşılaştırıldığı bir çalışmada, manda ST kası daha yüksek n-6 ve n-3 yağ asidi içeriğine sahip olduğu ve hem sığır ve hem de manda dokuları düşük n-6: n-3 yağ asidi oranına sahip olup, insan beslenmesinde yeterli ve dengeli yağ asidi sağlayacağını belirtmişlerdir (Betancourt ve ark., 2009).

Rao ve Kowale (1991) manda etlerinde doymuş yağ asitlerinden palmitik, stearik, oleik ve linoleik asitlerin olduğunu bildirmişlerdir. Nehir mandaları etinin, zebu sığırı etine kıyasla daha yüksek miktarda konjuge linoleik asit ( $1.83 \mathrm{mg} / \mathrm{g}$ yağ asidine karş1 1,47 mg/kg) içerdiği bildirilmiştir (Mendoza ve ark., 2005). Giordano ve ark. (2010), manda etinin daha düşük ateriyosiklorotik (damarsertliği) yükü ve oksidatif strese duyarlılık dahil olmak üzere kalp hastalıkları risk profili açısından önemli faydalar sağlayabileceğini göstermiştir.

İtalyan mandası ve simmental sı̆̆ırlarının karkas özelliklerinin karşılaştırıldığı bir araştırmada manda kas içi yağında stearik asit içeriği, SFA ve n6-PUFA/n3-PUFA oranı sığırlara göre daha yüksek (sırasıyla \% 21,5 ve \% 14,4; \% 44,4'e karş1 \% 36,9 ve 16,7'ye karş1 12,3) ve MUFA oranı düşük 
(\%18,6'ya karşı \%28,6) olarak saptanmıştır. Manda ve sığır etinin genel kabul edilebilirliği önemli ölçüde farklılık göstermemiş, ancak sığır etinin yumuşaklığı manda etinden önemli ölçüde daha iyi bulunmuştur. Bunun aksine, tüketiciler pişmiş manda etlerinin lezzetini, duyusal özellikleri ve genel kabul edilebilirliğinin yüksek olduğunu ve daha yüksek memnuniyet puanları verdikleri görülmüştür (Spanghero ve ark., 2004).

Dimov ve ark. (2012) dişi sığır ve manda etleri karşılaştırıldığında, manda etlerinin daha düşük oranda doymuş yağ asitlerine sahip olduğu, daha yüksek oranda stearik asit ve daha düşük palmitik ve miristik asit olduğunu saptamışlardır. Mandalar sığırlara kıyasla n-6/n-3 oranı $(7,00)$ ile iyi kaliteli et üretmişler, gruplar arasında toplam PUFA miktarı farklılıklarının ihmal edilebilir düzeyde olduğunu bildirmişlerdir.

Uriyapongson (2013) manda ve sığır etlerinin temel niteliklerinin (kas pH's1 (5.4), soğutma firesi (2\%), nem (76.6\%), protein $(19 \%)$ ve kül $(1 \%))$ benzer olduklarını bildirmişlerdir. Bununla birlikte, manda yağının beyaz renkli olduğu ve manda etinin sığır eti ile karşılaştırıldığında daha fazla pigmentasyon ve daha az kas içi yağ nedeniyle sığır etinden daha koyu renkte olduğunu göstermişlerdir. Duyusal analiz paneli testleri ve yumuşaklık ölçümleri, nehir manda etinin sı̆̆ır etine benzer olduğunu göstermişlerdir. Mandalarda bağ dokusu daha geç yaşta sertleşerek manda eti kalitesini iyileştirdiğinden sı ğır etine göre yumuşaklığını daha ileri bir yaşa kadar koruyabilir. Manda etleri ile ilgili kriterler farklı konsantre ve kaba yemlerle beslenmesi suretiyle değiştirebilir. Örneğin, Uriyapongson (2007) (naklen Rakiat, 2008) iki farklı merada otlayan mandaların et kalitesinde önemli farklılıklar meydana geldiğini ve iyi bir merada otlatmanın etin kimyasal yapısı bakımından daha iyi olduğunu, daha düşük trigliserit ve omega $6: 3$ oranına sahip olduğunu ve tüketilme kalitesini (çiğneme sertliği ve sululuğu) iyileştirdiğini bildirmiştir.

Sompratana (2008, Uriyapongson, 2013 'ten naklen), 350 gün boyunca 203 kg'lık mandalarda vücut ağırlığının \%1,5 ve \%2'si oranında konsantre yem verilmesinin etkisini araştırdıkları bir çalışmada, CA'nın \%2'si kadar kesif yem verilen mandalarda et kalitesinin daha iyi olduğunu ve \%1,5 kesif yem verilenlere göre daha düşük kollojen içerdiğini, kopma mukavemeti ve TBARS değerlerinin azalttı̆̆ını bildirmiştir.

Uriyapongson (2007) manda etinin \%74-78 su, \%18-24 protein, \%1-3 yağ ve \%1-2 kül içerdiğini bildirmiştir. Manda yaşlandıkça manda etindeki su oranı azalır, protein ve yağ oranı artar. Manda eti düşük kolesterol ve trigliserit içerir (sırasıyla sadece 56,9 mg/100 g kolesterol ve $1,15 \mathrm{~g} / 100 \mathrm{~g}$ trigliserit). Manda etinde ayrıca insan sağlığ omega-3 bulunur. Manda etindeki omega-6 ve omega-3, toplam yağın \%9,50 ve \%1,49'udur (Ziauddin ve ark., 1994).

Vitaminler insan vücudu için esansiyel bileşenlerden birisidir ve önemli bir kısmı yiyeceklerle dışarıdan alınmasının gerekliliği gayet iyi bilinmektedir. Yapılan bir çalışmada, $100 \mathrm{gr}$ taze manda etinde 0,045 mg vitamin B1, 0,253 mg vitamin B6, 2,131 mg vitamin B12, 0,848 $\mathrm{mg}$ vitamin A, 0,060 mg vitamin $\mathrm{E}$ ve 25,464 mg selenyum olduğu belirlenmiştir. Bununla birlikte, manda etinde belirlenen vitamin düzeyleri, vitamin A hariç, sığır, domuz, piliç ve hindi etlerinden düşük bulunmuştur. Araştırıcılar manda etindeki, bu düşük vitamin içeriğinin yemleme ile ilgili olduğunu ve üreticilerin manda yemlerine yeterli miktarda vitamin mineral karması katmaları gerektiğini bildirmişlerdir (Driskell ve ark., 1997).

\section{Manda Eti Üretim ve Tüketimini Artırma Yolları}

Manda üretimindeki bazı önemli sorunlar arasında azalan manda sayısı, üreme sorunları, yetersiz beslenme ve yetersiz hayvan sağlığı hizmetleri ve yönetim uygulamaları yer almaktadır. Daha büyük bir toplum kesimine ulaşmak için manda etinin farkındalığını ve popülerliğini artırmaya yönelik çalışmalar yapılmalıdır. Manda eti daha lifli, daha koyu, kaba ve daha az hassas olarak kabul edilir. Mandaların dünya çapında birçok ülkede evcilleştirilmesine ve manda etinin yaygın olarak tüketilmesine rağmen, bazı gelişmiş ülkelerde manda hala yabani bir hayvan olarak kabul edilmekte ve etleri av eti altında sınıflandırılmaktadır (Naveena ve Kiran, 2014). Manda etine talebin oluşturulabilmesi için bu çalışmada bahsedilen yargıların değiştirilmesi ve olumlu bakış açsının sağlanması gereklidir.

Bir kısım mandalar uzun yıllardır yük hayvanı olarak kullanıldıklarından kas gelişimleri oldukça ileri düzeyde ve stsertleşmiştir ve dolayısyla et kalitesi düşük olarak algılanmaktadır. Mandalar yağsız hayvanlardır ve benzer yoğun yemlerle beslenen sığır karkaslarına göre deri altında bulunan kabuk yağı dokuları daha azdır (Desmond, 1990). Yağ dağılımının dengesiz olması ve yağ azlığı etlerde sertliğin diğer bir sebebidir. Bununla birlikte, yağsız karkas verimi nedeniyle de yağsız et tüketimi tercih eden tüketiciler için talep oluşturabilir. Mandaların çoğu, üretkenlik veya çalışma ömürlerinin sonunda kesilir ve etleri koyu renkli, kaba ve serttir. $\mathrm{Bu}$ nedenle yapılacak çalışmalarda genç hayvanların besiye alınarak et amaçlı olarak kullanılmasıyla et kalitesi artırılarak tüketiciye sunulmalıdır. Dişi mandalar genellikle süt üretimi için yetiştirilir ve manda yetiştiricilerinin çoğu erkek buzağıları ihmal ederek ölmelerine izin vermektedirler (Naveena ve Kiran, 2014). Süt üretim amacıyla yetiştirilen dişi mandaların verim dönemleri sonunda ileri yaşlarda kesilmeleri et kalitesinde azalmaya neden olarak tüketici tercihini azaltan diğer faktör olarak bildirilmektedir. Ĕger toplam manda sayısı artırılarak seleksiyon ve ayıklama yoluyla düşük verimli ve üreme problemleri olan dişilerin erken dönemde besiye alınarak yaşlanmadan kesime sevkleri ile kaliteli etler elde edilebilir. Belirli etçi manda ırklarının geliştirilmesi ve erkek buzağılarının besiye alınmaları, sürdürülebilir et üretimini artırabilecektir. Manda eti, yetiştiriciye avantajları olan, değeri artacak çeşitli katma değerli ürünlere dönüştürülebilir ve pazarda kendi nişleri olan bir dizi tipik ürün yaratılabilir.

Sonuç olarak; mandalar bazı kutsal kabul edilen hayvanlar grubunda olmadığ 1 için etlerinin üretimi ve tüketiminin de dini açıdan da bir kısıtlama bulunmamaktadır. $\mathrm{Bu}$ nedenle herkes tarafından tüketilebileceğinden yaygın tüketimi artırılabilir. Diğer yandan bu zaman kadar yapılan çalışmalar, sığırlar gibi mandalara et yönünde bir seleksiyon olmadığını göstermiştir. Mandalar için 1slah çalışmalarının azlığg dikkate alınarak araştırma ve geliştirme sayılarının artırılması ve desteklenmesi sağlanmalıdır. Toplumda manda eti bilinirliliği ve tüketiminin yaygınlaştırılmasına ihtiyaç vardır. Aynı zamanda manda etinin katma değerli ürünlerde kullanılarak ve özel manda et ürünleri oluşturularak üretici gelirleri artırılmalıdır. Bunun yanında devlet tarafından sağlanan manda yetiştirmeyi destekleme projelerinin sürdürülmesi ve politikaların da çiftçi lehine iyileştirilmesi gereklidir.

\section{Kaynaklar}

Abdolghafour B, Ahmad Saghir, 2014. Buffalo: a potential animal 
for quality meat production- A review. Livestock Research International $\mathbf{2}$.

Acebrón LB, Dopico DC, 2000. The importance of intrinsic and extrinsic cues to expected and experienced quality: An empirical application for beef. Food Quality and Preference 11.

Aksoy Y, Şahin A, Ulutaş Z, Uğurlutepe E, 2021. The effect of different slaughter weights on some meat quality traits of musculus longissimus dorsi thoracis of male Anatolian buffaloes. Tropical Animal Health and Production 53.

Anjaneyulu ASR, Sengar SS, Lakshmanan V, Joshi DC, 1985. Meat quality of male buffalo calves maintained on different levels of protein. Buffalo Bulletin 4.

Astuti T, Sari RM, Santoso U, 2019. The effectiveness of forage and balanced concentrate feeding on the nutritional values and performance of buffaloes. Buffalo Bulletin 38, 285-290.

Banović M, Grunert KG, Barreira MM, Fontes MA, 2009. Beef quality perception at the point of purchase: A study from Portugal. Food Quality and Preference 20.

Betancourt L, Bustamante CA, Díaz GJ, 2009. Determination of the fatty acid composition in selected beef and buffalo tissues. Livestock Research for Rural Development 21.

Bonnet C, Bouamra-Mechemache Z, Réquillart V, Treich N, 2020. Viewpoint: Regulating meat consumption to improve health, the environment and animal welfare. Food Policy 97, 101847.

Borghese A, 2010. Development and perspective of buffalo and buffalo market in Europe and Near East. Revista Veterinaria 21.

Borghese A, 2013. Buffalo livestock and products in Europe. Buffalo Bulletin 32.

Calabrò S, Cutrignelli MI, Gonzalez OJ et al., 2014. Meat quality of buffalo young bulls fed faba bean as protein source. Meat Science 96.

Charles DD, 1982. Meat tenderness and palatability of Swamp buffalo and four breeds of cattle. Animal Production 34.

Daghir N, Diab-El-Harake M, Kharroubi S, 2021. Poultry production and its effects on food security in the Middle Eastern and North African region. Journal of Applied Poultry Research 30, 100110.

Dimov K, Kalev R, Tzankova M, Penchev P, 2012. Fatty-acid composition of the lipids in $\mathrm{m}$. longisimus dorsi of bovine and buffalo calves and buffalo cows. Bulgarian Journal of Agricultural Science $\mathbf{1 8 .}$

Duru S, Sak H, 2017. Türkiye'de Besiye Alınan Simmental, Aberdeen Angus, Hereford, Limousin ve Charolais Irk1 Sığırların Besi Performansı ve Karkas Özellikleri. Türk Tarım - Gida Bilim ve Teknoloji Dergisi 5, 1383-1388.

FAOStat, 2019. Food and Agricultural Organization. Animal Production Data. http://www.fao.org/faostat/en/\#data/QL Access:15.02.2021, 1-227.

Giordano G, Guarini P, Ferrari P, Biondi-Zoccai G, Schiavone B, Giordano A, 2010. Beneficial impact on cardiovascular risk profile of water buffalo meat consumption. European Journal of Clinical Nutrition 64.

Giuffrida-Mendoza M, de Moreno LA, Huerta-Leidenz N et al., 2015. Cholesterol and fatty acid composition of longissimus thoracis from water buffalo (Bubalus bubalis) and Brahmaninfluenced cattle raised under savannah conditions. Meat Science 106.

Infascelli F, Gigli S, Campanile G, 2004. Buffalo meat production: Performance infra vitam and quality of meat. Veterinary Research Communications 28.
Irurueta M, Cadoppi A, Langman L, Grigioni G, Carduza F, 2008. Effect of aging on the characteristics of meat from water buffalo grown in the Delta del Paraná region of Argentina. Meat Science 79.

Joksimovic J, Ognjanovic A, 1977. Comparison of carcase yield, carcase composition and quality characteristics of buffalo meat and beef. Meat Science $\mathbf{1}$.

Kandeepan G, Anjaneyulu ASR, Kondaiah N, Mendiratta SK, Lakshmanan V, 2009. Effect of age and gender on the processing characteristics of buffalo meat. Meat Science $\mathbf{8 3}$.

Kandeepan G, Biswas S, 2007. Effect of low temperature preservation on quality and shelf life of buffalo meat. American Journal of Food Technology 2.

Kandeepan G, Mendiratta SK, Shukla V, Vishnuraj MR, 2013. Processing characteristics of buffalo meat-a review. Journal of Meat Science and Technology $\mathbf{1}$

Kiran M, Naveena BM, Reddy KS et al., 2016. Understanding tenderness variability and ageing changes in buffalo meat: Biochemical, ultrastructural and proteome characterization. Animal 10.

Kul E, Filik G, Şahin A, Çayıroğlu H, Uğurlutepe E, Erdem H, 2018. Effects of Some Environmental Factors on Birth Weight of Anatolian Buffalo Calves. Turkish Journal of Agriculture - Food Science and Technology 6.

Lambertz C, Panprasert P, Holtz W et al., 2014. Carcass characteristics and meat quality of swamp buffaloes (bubalus bubalis) fattened at different feeding intensities. AsianAustralasian Journal of Animal Sciences 27.

Landi N, di Giuseppe AMA, Ragucci S, di Maro A, 2016. Free amino acid profile of Bubalus bubalis L. meat from the Campania region. Revista Brasileira de Zootecnia 45.

Lapitan RM, Del Barrio AN, Katsube O et al., 2007. Comparison of carcass and meat characteristics of Brahman grade cattle (Bos indicus) and crossbred water buffalo (Bubalus bubalis). Animal Science Journal 78

Li Q, Wang Y, Tan L et al., 2018. Effects of age on slaughter performance and meat quality of Binlangjang male buffalo. Saudi Journal of Biological Sciences 25.

Marchello MJ, Driskell JA, 2001. Nutrient composition of grassand grain-finished bison. In: Great Plains Research.

Mendoza G De, M., Moreno A De et al., 2005. Occurrence of conjugated linoleic acid in longissimus dorsi muscle of water buffalo (Bubalus bubalis) and zebu-type cattle raised under savannah conditions. Meat Science 69.

Nanda AS, Nakao T, 2003. Role of buffalo in the socioeconomic development of rural Asia: Current status and future prospectus. Animal Science Journal 74.

Naveena BM, Kiran M, 2014. Buffalo meat quality, composition, and processing characteristics: Contribution to the global economy and nutritional security. Animal Frontiers 4, 18-24.

Neath KE, Del Barrio AN, Lapitan RM et al., 2007. Difference in tenderness and $\mathrm{pH}$ decline between water buffalo meat and beef during postmortem aging. Meat Science $\mathbf{7 5 .}$

Nordoy A, Goodnight SH, 1990. Dietary lipids and thrombosis. Relationships to atherosclerosis. Arteriosclerosis $\mathbf{1 0 .}$

O’Quinn TG, Legako JF, Brooks JC, Miller MF, 2018. Evaluation of the contribution of tenderness, juiciness, and flavor to the overall consumer beef eating experience. Translational Animal Science $\mathbf{2}$.

Paleari MA, Camisasca S, Beretta G et al., 1997. Comparison of the physico-chemical characteristics of buffalo and bovine meat. Fleischwirt. Fleischwirt. Intern. 6.

Ranjhan SK, 2013. Latest concepts in rearing buffaloes for meat 
production. Buffalo Bulletin 32.

Rao VK, Kowale BN, 1991. Changes in phospholipids of buffalo meat during processing and storage. Meat Science $\mathbf{3 0}$.

Rashad AMA, EL-Hedainy DK, Mahdy AE, Badran AE, ElBarbary ASA, 2019. Utilization of live body weight, measurements, and eye muscle components to predict carcass performance of fattened Egyptian male buffalo calves. Tropical Animal Health and Production 51.

Robertson J, Ratcliff D, Bouton PE, Harris P V., Shorthose WR, 1986. A Comparison of Some Properties of Meat from Young Buffalo (Bubalus bubalis and Cattle. Journal of Food Science $\mathbf{5 1}, 47-50$.

Sarwar M, Khan MA, Nisa M, Bhatti SA, Shahzad MA, 2009. Nutritional management for buffalo production. AsianAustralasian Journal of Animal Sciences 22.

Sharma N, Gandemer G, Goutefongea R, Kowale BN, 1986. Fatty acid composition of water buffalo meat. Meat Science $\mathbf{1 6}$.

Spanghero M, Gracco L, Valusso R, Piasentier E, 2004. In vivo performance, slaughtering traits and meat quality of bovine (Italian Simmental) and buffalo (Italian Mediterranean) bulls. Livestock Production Science 91.

Suleman R, Wang Z, Aadil RM, Hui T, Hopkins DL, Zhang D, 2020. Effect of cooking on the nutritive quality, sensory properties and safety of lamb meat: Current challenges and future prospects. Meat Science 167, 108172.

Tamburrano A, Tavazzi B, Callà CAM et al., 2019. Biochemical and nutritional characteristics of buffalo meat and potential implications on human health for a personalized nutrition. Italian Journal of Food Safety $\mathbf{8}$.

Tateo A, De Palo P, Quaglia NC, Centoducati P, 2007. Some qualitative and chromatic aspects of thawed buffalo (Bubalus bubalis) meat. Meat Science $\mathbf{7 6}$.

Terramoccia S, Bartocci S, Amici A, Martillotti F, 2000. Protein and protein-free dry matter rumen degradability in buffalo, cattle and sheep fed diets with different forage to concentrate ratios. Livestock Production Science $\mathbf{6 5}$.

Uğurlu M, Kaya I, Saray M, 2016. Effects of some environmental factors on calf birth weight and milk yield of Anatolian Water Buffalo (Bubalus bubalis). Bulgarian Journal of Agricultural Science 22.

Ulutaş Z, Şahin A, Aksoy Y, Uğurlutepe E, 2021. Determination of slaughter and carcass traits in male Turkish Anatolian buffaloes at different slaughter weights. Turkish Journal of Veterinary and Animal Sciences 45.

Uriyapongson J, 2007. Comparison and improvement of chemical and physical characteristics of low- fat ground beef and buffalo meat patties at frozen storage. Italian Journal of Animal Science $\mathbf{6}$.

Uriyapongson S, 2013. Buffalo and buffalo meat in Thailand. Buffalo Bulletin 32.

Valin C, Pinkas A, Dragnev H, Boikovski S, Polikronov D, 1984. Comparative study of buffalo meat and beef. Meat Science 10.

Wanapat M, Kang S, 2013. World buffalo production: Challenges in meat and milk production, and mitigation of methane emission. Buffalo Bulletin 32.

Yılmaz Adkinson A, Konca Y, 2021. Sütçü Manda Irklarının Performans ve Verimliliğini Etkileyen Faktörler ve Türkiye'deki Geleceği. European Journal of Science and Technology 25, 498-508.

Ziauddin S, Mahendrakar K, Rao NS, Ramesh DN, B. S. Amla BL, 1994. Observations on some chemical and physical characteristics of buffalo meat. Meat Science 37, 103-113. 